\title{
Correlation Between Serum Ferritin and Testosterone Level in Adolescent Male with Transfusion Dependent Thalassemia
}

\author{
Raja Iqbal Mulya Harahap, Nina Tristina, Delita Prihatni, Dewi Kartika Turbawaty \\ Department of Clinical Pathology Faculty of Medicine Universitas Padjadjaran \\ Dr. Hasan Sadikin General Hospital Bandung, Indonesia
}

\begin{abstract}
Transfusion-dependent thalassemia (TDT) is a type of beta-thalassemia that needs regular and long-term blood transfusions. Complications can occur due to the deposition of iron in TDT patients, including endocrine complications causing deficiency of testosterone that plays a role in the secondary sexual development in males. The objective of this study was to understand the correlation between ferritin and testosterone level in male adolescences with transfusion-dependent thalassemia. This cross-sectional observational correlative study was conducted from April to August 2019 on 74 males aged 12-18 years old who were presented to the Thalassemia Outpatient clinic, Dr. Hasan Sadikin General Hospital, Bandung. Blood was collected using phlebotomy for ferritin and total testosterone serum examination. Data were then analyzed using SPSS version 17.0. Low testosterone level $(<3.0 \mathrm{ng} / \mathrm{mL})$ was found in $63.5 \%$ of subjects. Results of the Spearmen correlation test demonstrated a negative correlation with $r:-0,699$ and $p$-value $<0.001$, showing a negative, strong, and significant correlation among those variables. The higher ferritin level in TDT patients indicates a high level of the free iron level in the body that can destroy the endocrine organs and cause deprivation of testosterone secretion, leading to hypogonadism in transfusion dependent thalassemia patients.
\end{abstract}

Keywords: Ferritin, iron, transfusion dependent thalassemia, total testosterone

\section{Korelasi Kadar Feritin dengan Testosteron Total Serum Remaja Penderita Transfusion Dependent Thalassemia}

\begin{abstract}
Abstrak
Transfusion dependent thalassemia (TDT) adalah kondisi talasemia beta yang membutuhkan transfusi darah secara terus menerus. Komplikasi dapat terjadi akibat penumpukan zat besi pada pasien TDT diantaranya komplikasi endokrin yang menyebabkan defisiensi testosteron sebagai hormon yang berperan pada perkembangan seksual sekunder pada laki-laki. Tujuan penelitian ini untuk mengetahui korelasi kadar feritin dengan testosteron total serum pada remaja laki-laki penderita transfusion dependent thalassemia. Penelitian ini adalah penelitian observasional korelatif dengan rancangan potong lintang yang dilakukan pada April hingga Agustus 2019, dengan subjek adalah 74 pasien laki-laki berusia 12-18 tahun dari Poliklinik Thalassemia Departemen Ilmu Kesehatan Anak Rumah Sakit Dr. Hasan Sadikin Bandung. Pengambilan darah dilakukan pada pagi hari dengan flebotomi untuk pemeriksaan kadar feritin dan testosteron total serum. Data kemudiaan dianalisis dengan SPSS versi 17.0. Kadar testosterone rendah $(<3.0 \mathrm{ng} / \mathrm{mL})$ ditemukan pada 63,5\% subjek penelitian. Uji korelasi Spearman antara kadar feritin dengan testosteron total serum didapatkan korelasi negatif sebesar $-0,699$ dengan $\mathrm{p}<0.001$ yang menunjukkan korelasi kuat dan bermakna antara ferritin dan testosteron. Semakin tinggi kadar feritin dalam tubuh subjek menggambarkan tingginya kadar zat besi bebas yang merusak organ termasuk organ endokrin seperti hipofisis dan testis dan hal ini mampu menyebabkan penurunan sekresi testosteron yang berakibat terjadi hipogonadisme pada penderita transfusion dependent thalassemia.
\end{abstract}

Kata kunci: Feritin, transfusion dependent thalassemia, testosteron total, zat besi

CorrespondingAuthor: Raja Iqbal Mulya Harahap,DepartmentofClinical Pathology Faculty of Medicine Universitas Padjadjaran/ Dr. Hasan Sadikin General Hospital Bandung, Jalan Pasteur No 38 Bandung, Indonesia, Email: rajanafiah@gmail.com 


\section{Introduction}

Thalassemia is a group of genetic diseases caused by a production defect due to a mutation in one or more globin chains of erythrocytes. The defect will cause unbalanced globin chain synthesis, ineffective erythropoiesis, and various degrees of anemia. ${ }^{1}$ Based on transfusion requirement, thalassemia is divided into two different groups: transfusion-dependent thalassemia and nontransfusion dependent thalassemia. Transfusiondependent thalassemia is thalassemia that needs routine and long-life transfusion to repair tissue oxygenation. ${ }^{1}$

Blood transfusion is the main treatment of transfusion dependent thalassemia . Long-term transfusion can cause several complications. ${ }^{2}$ One of the probable complications in a transfusion dependent thalassemia patient (TDT) patient is endocrine complications due to the incremental rise of free iron in serum, which enable the deposition of iron in an endocrine organ, leading to lipid peroxidation and formation of reactive oxygen species (ROS), which could lead to the presence of hormone-producing cells. ${ }^{3,4}$

In every patient suffering from transfusiondependent thalassemia (TDT), iron deposition may occur in iron-sensitive organs, such as hypophysis and testis. This may cause endocrine complications, such as hypogonadotropic and hypogonadism, because of the damages of the endocrine cells. ${ }^{5}$ Hypogonadotropic may also cause disruption of production and secretion of follicle stimulating hormone (FSH) and luteinizing hormone (LH), which play a role in testosterone's synthesis and spermatogenesis. This phenomenon could cause impairment of testosterone production. ${ }^{5,6}$

The prevalence of delayed puberty as well as testosterone deficiency in male adolescence with TDT is around 40-60\%; however, early diagnosis of this conditions is problematic especially in countries with limited resource due to the limited availability of laboratories that have the capacity for hormone testing and its related high cost. This leads to the fact that in these countries, the testosterone and other sexual hormone testing a is not routinely performed in TDT patients, and this can cause delay the delayed puberty diagnosis and its proper management for these patients. ${ }^{7}$

Several laboratory parameters can be used to monitor the iron deposition in thalassemia patients. Recommended parameters to be used as iron deposition monitoring of thalassemia patients includes ferritin, because it is less invasive, easy to examine, with good correlation with liver iron concentration as the gold standard of iron status examination. It is also recognized that ferritin is the most feasible parameter that can be used to monitor the iron level in blood. This study aimed to measure the strength of correlation between serum ferritin and total testosterone level among transfusion dependent thalassemia patients to detect the possibility of infertility earlier in the thalassemia patients. ${ }^{8}$

\section{Methods}

This cross-sectional study was conducted from April to August 2019 by applying the consecutive sampling method. Approval was obtained from the Health Research Ethic Committee of Dr. Hasan Sadikin General Hospital Bandung, Indonesia, with the issuance of the ethical clearance number LB.02.01/X.6.5/25/2019. The subjects in this study were adolescent male patients aged 12-18 years old who have been diagnosed with transfusion-dependent thalassemia by the pediatrician from the Department of Child Health Faculty of Medicine Universitas Padjajaran/Dr. Hasan Sadikin General Hospital Bandung. The research material of this research is serum for total testosterone and ferritin test. The serum was taken from $3 \mathrm{cc}$ blood which was taken from a phlebotomy procedure.

The ferritin examination was conducted with chemiluminescence immunoassay method. The serum, as study material, was stable for 3 days in $15-25^{\circ} \mathrm{C}, 7$ days in $2-8^{\circ} \mathrm{C}$, and 6 months in $-80^{\circ} \mathrm{C}$. The total testosterone level examination was conducted with micro-ELISA method. The stability of the study material was 8 hours in $18-2518-25^{\circ} \mathrm{C}$, 4 days in $2-8^{\circ} \mathrm{C}$, and 6 months in $-80^{\circ} \mathrm{C}$. Both tests were conducted at the Clinical Pathology Laboratory of Dr. Hasan Sadikin General Hospital, Bandung, Indonesia.

Data collected were then analyzed using the Statistical Package for the Social Science (SPSS) version 18.0. Normality test was conducted for ferritin and total testosterone level using the Kolmogorov-Smirnov test while the bivariate analysis was conducted to measure the strength of correlation between ferritin and total testosterone level. The bivariate analysis was performed using Pearson's correlation test if both of the variable were distributed normally, and with Spearman's correlation test if one or both variables were not distributed normally. 
RIM Harahap et al: Correlation Between Serum Ferritin and Testosterone Level in Adolescent Male with Transfusion Dependent Thalassemia

Table 1 Subject Characteristics

\begin{tabular}{lccc}
\hline \multicolumn{1}{c}{ Variable } & $\begin{array}{c}\text { Amount (n=74) } \\
(\%)\end{array}$ & $\begin{array}{c}\text { Median } \\
\text { (Range) }\end{array}$ & Distribution \\
\hline Age (years) & & $14.65(12-18)$ & p: 0.019 \\
(abnormal distribution) & \\
Duration of Diagnosis (years) & $0(0)$ & \\
$<5$ & $7(9.5)$ & \\
$5-10$ & $67(90.5)$ & \\
$>10$ & $74(100)$ & \\
Chelation Type & $0(0)$ & \\
Oral chelation & \\
No chelation & $3(4.1)$ & \\
Splenectomy History & $71(95.9)$ & \\
Yes & \\
No & $36(48.6)$ & \\
Nutritional Status & $38(51.4)$ & \\
Underweight & & \\
Normoweight & & \\
\hline
\end{tabular}

\section{Results}

The subjects of this study were adolescent males with transfusion dependent thalassemia visited the Thalassemia Clinic of the Department of Child Health, Dr. Hasan Sadikin General Hospital, Bandung, Indonesia. Seventy-four subjects met the inclusion and exclusion criteria, and their parents signed an informed consent form to agree to participation in this study.

Descriptive analysis and characteristics of the subjects were listed in Table 1, including age, duration of diagnosis, type of chelation, history of splenectomy, and nutritional status according to the body mass index/age ratio of the WHO standard. The ferritin level and total testosterone level are presented in Table 2.

In this study, both of serum ferritin and total testosterone levels were distributed abnormally, that the correlation between variables were measured and analyzed using the Spearman's correlation test. The correlations between the

Table 2 Serum Ferritin and Testosteron Levels among Subjects

\begin{tabular}{lcc}
\hline \multicolumn{1}{c}{ Variables } & Amount (\%) & Median (Range) \\
\hline $\begin{array}{l}\text { Ferritin Level (ng/mL) } \\
\quad<2500\end{array}$ & $25(33.8)$ & \\
$\quad \geq 2500$ & $49(66.2)$ & $4452.35(1009.2-16500)$ \\
Testosterone Level (ng/mL) & & \\
$\quad<3.0$ & $47(63.5)$ & \\
$3.0-12.0$ (normal) & $27(36.5)$ & $1.36(0.06-10.27)$ \\
$>12.0$ & $0(0)$ & \\
\hline
\end{tabular}

Table 3 Correlation between Serum Ferritin and Testosterone Levels of Transfusion Dependent Thalassemia Male Adolescent Patients

\begin{tabular}{ccc}
\hline Variable & R-value (CI 95\%) & p-Value \\
\hline Ferritin with Testosterone level & -0.699 & $<0.001^{*}$ \\
\hline
\end{tabular}

$\mathrm{r}=$ Spearman rank correlation; $\mathrm{CI}=$ confidence interval 


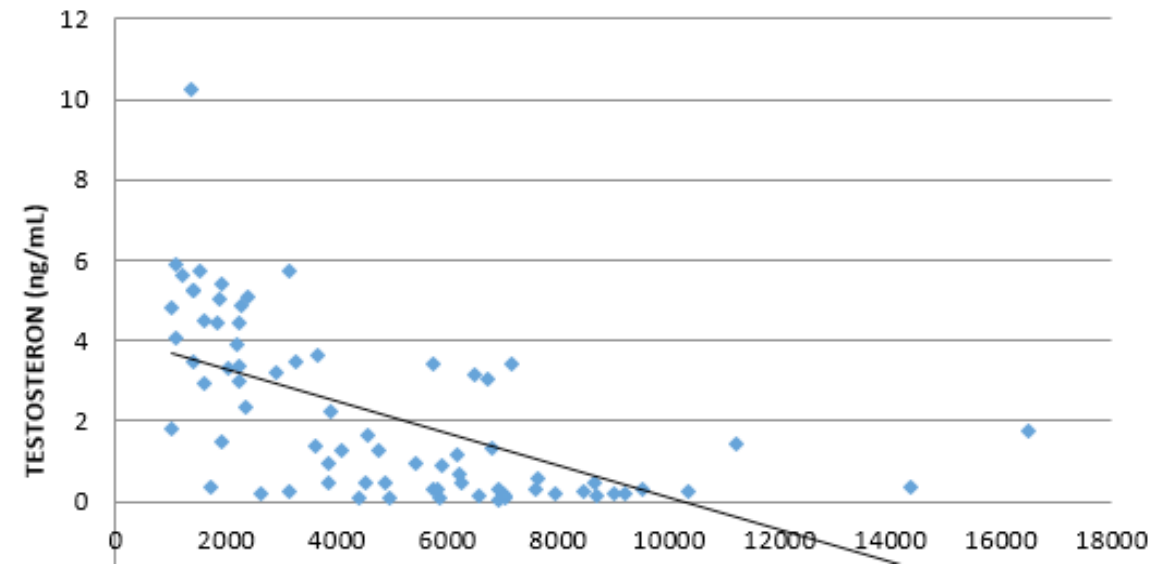

Figure Correlation of Ferritin and Testosteron in Subjects

parameters are presented in Table 3 and Figure. The chart that plots the correlation between Ferritin and Testosterone is presented in the Figure.

\section{Discussion}

Blood transfusion is very crucial in the survival of $\beta$-thalassemia major patients, but this lifesaving transfusion have a serious disadvantage in the form of the inexorable accumulation of iron in the tissues. Excess iron is extremely toxic to all cells of the body and can cause serious and irreversible end-organ damages, if untreated, as the TDT children grow into adolescence and adulthood. ${ }^{9}$

This study shows that patients participated in the study have a high significant increase in serum ferritin level that is most likely due to frequent blood transfusions and hemolysis of red blood cells. Iron overload in TDT patients, as predicted by high serum ferritin level, could be caused by frequent blood transfusions, hemolysis of red blood cells, and increased gastrointestinal iron absorption due to the paradoxical hepcidin suppression from dyserythropoiesis. ${ }^{9}$

Along with those findings, this study revealed that of the 74 subjects, 47 had testosterone deficiency (63.5\%) while 27 subjects (36.5\%) had a normal testosterone level. A study by Mula-Abed in Oman demonstrated that the prevalence of hypogonadism in transfusion is $73.3 \%$, with $50 \%$ of these patients experienced hypogonadotropic hypogonadism. Another study from Khan in Pakistan in 2014 showed that the prevalence of hypogonadism among transfusion dependent thalassemia male patients is $52.4 \%$, while Vahidi stated that, in India, the prevalence of low testosterone alongside with delayed puberty was 53,3\% in 2003.,10

This study also discovered that 27 (36.5\%) subjects had normal testosterone level. Normal testosterone level in this study may link to the adherence of the subjects to chelation therapy, since 21 of 27 subjects (77.78\%) with a normal testosterone level had a ferritin level of $<2500$ $\mathrm{ng} / \mathrm{mL}$, showing a controlled chelation status. Both oral or subcutaneous chelation processes could reduce the unbound iron, which is cellular toxic. From 27 (36.5\%) subjects with a normal testosterone level, almost all subjects have a low to normal testosterone level of 3.0-5.0 ng/ $\mathrm{mL}$. Yet, there is 1 outlier with a normal to high testosterone level (10.27 ng/mL). An in-depth analysis of this patient showed that he had good adherence to chelation therapy, and for the past year, he had a low ferritin level. Furthermore, the subject was already 18 years old, which is the end of the adolescent age. These may contribute to the higher level of testosterone compared to other subjects. ${ }^{11}$

Endocrine glands have extreme sensitivity to iron toxicity, because they have high levels of transferrin receptors that promote iron accumulation and, thus, increase their vulnerability to iron toxicity. The iron stored in endocrine glands binds to the intracellular transferrin and, as the maximum storage capacity of transferrin gets exceeded, the pathological quantity of metabolically active iron catalyses the formation of free radicals. Most endocrine 
abnormalities recognized in developed countries were identified after ten years of age. However, in developing countries, it is possible to have a high prevalence of endocrine complications at an early age due to suboptimal of transfusions and chelation therapy. ${ }^{9}$

A negative and strong correlation between ferritin and total testosterone levels that is statistically significant was identified in this study. It is widely known that there are multifactorial causes of testosterone deficiency, such as genetic factors, age, body mass index, physical activity, and other external causes like medicines and other medical conditions. In this study, two of the causes of testosterone deficiency are hypogonadotropic and hypogonadism due to iron deposition in endocrine organs, especially in hypophysis and testis. The iron deposition will produce excess free radicals, then promote destruction of hormone-secreting cells in testis. In this study, this phenomenon can be proven by the strong correlation between serum ferritin and total testosterone levels among subjects. ${ }^{11,12}$

Clinically, testosterone deficiency experienced by thalassemia patients may decrease the quality of life, which is linked to its specific symptoms such as low sexual and reproduction functions, delayed growth and secondary sexual symptoms, and non-specific symptoms that include mood disorders, hypotimia, and others. Nevertheless, this disorder is still not routinely diagnosed in adolescent males with transfusion dependent thalassemia that patients with this condition are often not recognized and undertreated. Hence, the findings of this study may lay a foundation for another milestone for advanced research to provide evidence for including testosterone screening as the routine part of the management of transfusion dependent thalassemia male patients to increase their life expectancy and quality of life. ${ }^{13,14}$

Despite its positive effects on male sexual function, growth, and development, the role of testosterone in spermatogenesis is still somehow controversial. Also, Follicle Stimulating Hormone (FSH) and Luteinizing Hormone ( $\mathrm{LH})$ are the most influencing hormones in spermatogenesis. Since an improper exogenous testosterone therapy can also negatively affect the hypothalamic-pituitary gonadal axis and inhibit the production of follicle stimulating hormone and luteinizing hormone, this type of therapy should be approached cautiously. ${ }^{9,15}$

The descriptive analytic approach used in this study carries several unavoidable weaknesses. One of the weaknesses is that the measurements of ferritin and testosterone are not followed by the measurements of other hormones and proteins, such as the measurement of FSH, LH, and Sex Hormone Binding Globulin levels. Some studies suggest that measurement of biomarker levels should be performed to know the exact cause of testosterone deficiency, and how far the impairment of sexual functions occurs in the subjects.

This study suggests that increased ferritin is found along with low testosterone level in some TDT patients. There is also a strong, negative, and statistically significant correlation between serum ferritin and total testosterone level among transfusion dependent thalassemia male adolescent patients. It could be concluded also that the higher ferritin level may cause lower testosterone in TDT male patients. Further studies on follicle stimulating hormone (FSH), Luteinizing Hormone (LH), and Sex Hormone Binding Globulin (SHBG) are necessary to determine the exact cause of hypogonadism in the transfusion dependent thalassemia patients.

\section{References}

1. Keohane EM. Thalassemia. Dalam: Keohane EM, Smith LJ, Walenga JM, editor. Rodak's Hematology: Clinical Principles and Applications. 6th ed. New Jersey: Elsevier; 2018.

2. Galanello R, Origa R. Beta-thalassemia. Orphanet J Rare Dis. 2010;5:11.

3. Mishra AK, Tiwari A. Iron overload in beta thalassaemia major and intermedia patients. Maedica (Bucur). 2013;8(4):328-2.

4. Maggio M, De Vita F, Fisichella A, Lauretani F, Ticinesi A, Ceresini G, et al. The role of the multiple hormonal dysregulation in the onset of "anemia of aging": focus on testosterone, IGF-1, and thyroid hormones. Int J Endocrinol. 2015;3(3):226-35.

5. Mula-Abed W-A, Hashmi HA, Mushlahi MA, Muslahi HA, Lamki MA. Prevalence of endocrinopathies in patients with betathalassaemia major -a cross-sectional study in Oman. Oman Medical Journal. 2014;23(4):1-6.

6. Saliba AN, Harb AR, Taher AT. Iron chelation therapy in transfusion-dependent thalassemia patients: current strategies and future directions. Blood Med. 2015;6:197209.

7. De Sanctis V, Soliman AT, Elsedfy H, Di Maio S, Canatan D, Soliman N, et al. Gonadal 
dysfunction in adult male patients with thalassemia major: an update for clinicians caring for thalassemia. Expert Rev Hematol. 2017;10(12):1095-106.

8. Siripunthana $\mathrm{S}$, Sahakitrurungruang $\mathrm{T}$, Wacharasindhu S, Sosothikul D, Supornsilchai $\mathrm{V}$. Testicular function in patients with regular blood transfusion for thalassemia major. Asian Biomedicine. 2015;9(2):185-91.

9. Huda Tutor, Al-Ali Zainal. Evaluation of reproductive hormones in patients with $\beta$-thalassemia major in Misan Province, Iraq. Medicolegal Update. 2020;20(2):274-83.

10. Sinharay M, Mitra S, Dasgupta A. Effect of iron overload on gonadotrophins and organ sex steroids in pubertal thalassemia patients. Int J Cur Res Rev. 2017;9(23):15-21.

11. Dumaidi K, Al-Jawabreh A, Al-Assi S. Assessment of gonadal and thyroid function for adult transfusion - dependent $\beta$-thalassemic patients in Palestine. Jordan
Medical Journal. 2015;49(1):17-26.

12. Paduch DA, Brannigan RE, Fuchs EF, Kim ED, Marmar JL, Sandlow JI. The Laboratory diagnosis of testosterone deficiency. Urology. 2014;83(5):980-8.

13. Yaghobi M, Miri-Moghaddam E, Majid N, Bazi A, Navidian A, Kalkali A. Complications of transfusion-dependent $\beta$-thalassemia patients in Sistan and Baluchistan, SouthEast of Iran. Int J Hematol Oncol Stem Cell Res. 2017;11(4):268-72.

14. Sleiman J, Tarhini A, Bou-Fakhredin R, Saliba AN, Cappellini MD, Taher AT. Nontransfusion-dependent thalassemia: an update on complications and management. Int J Mol Sci. 2018;19(1):182

15. Saffari F, Mahyar A, Jalilolgadr S. Endocrine and metabolic disorders in $\beta$-thalassemia major patients. Caspian J Internal Med. 2012;3(3):466-72. 